\title{
COMPARING THE SPECIFIC GRAVITY AND WATER ABSORPTION RATE OF MECHANICALLY AND LOCALLY CRUSHED AGGREGATES
}

\author{
Bassah Emmanuel John \\ Faculty of Engineering \\ Federal University Wukari, Taraba State, Nigeria
}

\author{
Joshua Williams Kwari \\ Faculty of Engineering \\ Federal University Wukari, Taraba State, Nigeria
}

\begin{abstract}
The need for assessing construction materials is becoming a priority within the construction industry. This trend is necessitated by the high diminishing rate of construction materials, pressing demand on existing quarries, rising cost of aggregates and failures of civil structure all over the country. This research is aimed at assessing the suitability of hand crushed aggregates for use in construction as compared to the old tradition of mechanically crushed aggregates. A one-sample t-Test was carried out to test for the significant difference in the means in comparison to the standard guidelines. From findings of the t-Test conducted to test the hypothesis, there was a significant difference in the specific gravity of hand crushed $(H C)$ aggregates $(p=0.001)$ for sample sites $X, Y$ and $Z$. Furthermore, there was also a significant difference in the water absorption of mechanically crushed (MC) and hand crushed (HC) aggregates for sample site $\mathrm{Z}$ ( $p=0.001$ and $p=0.025$ ). However, there was no significant difference in the specific gravity of MC for sample sites $X$, $Y$ and $Z$ with $p$ values of $0.107,0.539$ and 0.188 , respectively. Although some of the results shows conformity to the stipulated building standards of an average specific gravity 2.7 and average water absorption rate of $0.6 \%$, it is still imperative to reassess their suitability before use in constructions. These aggregates cost less and widely used within the study area, hence becomes imperative to evaluate their suitability before use in any construction project.
\end{abstract}

Keywords - Specific gravity, water absorption, aggregates, hand crushed, mechanically crushed, construction materials

\section{INTRODUCTION}

Aggregates generally occupy between 75 to $85 \%$ by volume of concrete in which their properties can have a significant effect on the mechanical properties, durability, service life and cost of concrete [1,2]. Apart from concrete, aggregates have also been used in road constructions to form the road base structure of the pavement [3], hence, can affect the durability of road pavements. This indicates the importance of aggregates in the construction industries and how useful it is to understand this precious resource. They have an amazing variety of uses; imagine a world without roads, bridges, bricks, concrete etc. in fact, every town (no matter how big or small) utilizes aggregates in so many ways. Aggregates could be in the form of crushed stones, sand, and gravel $[1,4]$, which makes them the most abundant resource for construction.

According to Tucker [5] using the right type of aggregate as well as the right quality of aggregate is an important factor that needs to be considered in concrete mix design as well as in road construction. The fine and coarse aggregate generally occupy $60-75 \%$ of the concrete volume ( $70-80 \%$ by mass). Aggregates are broad category of coarse particulate materials used in diverse of construction activities, they include sand, gravel, crushed stone, slag, recycled concrete and geosynthetic aggregates [3]. Aggregates have been used in concrete, road base constructions, drainages, dam embankments and spill ways, foundations and many other constructions works.

Aggregates are amongst the most abundant natural resource in Plateau state Nigeria due to the abundant nature of rocks within the region. This has made men, women and young one's venture into the business of crushing rocks to make ends meet. However, there is the need to investigate the difference between hand crushed (manually crushed) and mechanically crushed rocks in terms of its physical properties in order to ensure that they meet standard requirements and that there is no significant difference that can affect durability during use in the construction industry. This will enable construction professionals make the right decision as to which type of aggregate to use, where and why. Hand crushed aggregates are usually cheaper and so, the choice of majority who desire to construct within the Jos axis. With the vast majority choosing hand crushed aggregates, this research is set to investigate the difference in terms of its physical properties to ensure that there will be no significant effect in concrete mix and the durability of the concrete as well as in road base or grade construction. 


\section{International Journal of Engineering Applied Sciences and Technology, 2020 \\ Vol. 5, Issue 2, ISSN No. 2455-2143, Pages 1-7 \\ Published Online June 2020 in IJEAST (http://www.ijeast.com)}

\section{PARTICLE SIZE DISTRIBUTION (Grading)}

The distribution of aggregate particle size, otherwise known as 'grading', is an important property for all construction aggregates and it often defines the type of material [6,7]. The particle size distribution is usually graded, and this is usually carried out by sieve analysis as shown in Figure 1 below. The sample is passed through a sieve stack (wet or dry) and the weight proportion retained on each sieve is determined. This is important in every construction industry as the cumulative percentage finer than each sieve size is plotted to produce 'particle-size distribution curves'. Aggregate should be clean (free of clay, silt, and dust) to ensure effective binding of cement or bitumen [6]. Sedimentation methods may also be used to determine the grading of fines. Another important property of aggregate is its particle shape. The shape of aggregate particles is a product of the rock type, depositional environment and quarrying and production process [6,8]. For example, hard, tough, or brittle rocks will often generate more flakes, whereas softer rocks produce more fines. Angular, cuboidal aggregate is usually preferred [9]. Flat, flaky, or long, thin particles will not interlock well and result in weak road stone or concrete products [7]. Also, poorly shaped aggregate has a high surface area and has a high demand for binder [6]. Aggregate shape is determined using petrographic analysis and can be classified as: rounded, cuboidal, irregular, angular, flaky, or elongated [6]. Flakiness and elongation are the key measures of poor particle-shape. The 'flakiness' of an aggregate is measured as the weight proportion passing a specially designed slotted sieve [6]. A limit of 35\% flaky particles is imposed for general purpose construction aggregate whereas a stricter limit of $25 \%$ flaky particles is imposed for wearing course road stone [7].

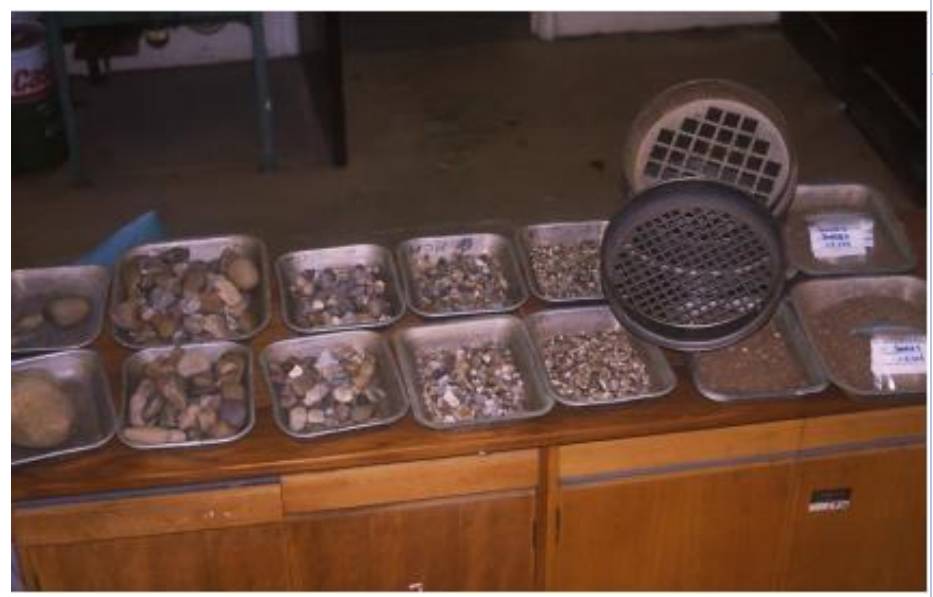

3 According to Unit Weight

\section{A. Aggregate ClaSSIFICATION}

Aggregate can be classified or divided into several categories depending on different criteria by different bodies, organizations, countries, and codes. Aggregate can be classified according to size, source, and the unit weight [6]. Table 1 below shows a brief illustration of the various classification based on the size weight and source of aggregate.

Table 1: Aggregate classification based on size, source, and unit weight [9]

\begin{tabular}{|c|c|c|}
\hline $\mathbf{S} / \mathbf{N}$ & $\begin{array}{c}\text { Aggregate } \\
\text { Classification }\end{array}$ & Sub-classification \\
\hline $\mathbf{1}$ & According to Size & $\begin{array}{l}\text { Coarse aggregate: these are } \\
\text { aggregates that are } \\
\text { predominantly retained on } \\
\text { sieve No. } 4(4.75 \mathrm{~mm}) \\
\text { Fine aggregate: these are } \\
\text { aggregate that pass through } \\
\text { sieve No. } 4 \text { and are } \\
\text { predominantly retained in } \\
\text { sieve No. } 200(75 \mu \mathrm{m}) \text {. they } \\
\text { are referred to as sand }\end{array}$ \\
\hline 2 & $\begin{array}{l}\text { According to } \\
\text { Source }\end{array}$ & $\begin{array}{l}\text { Natural aggregate: these } \\
\text { aggregates are normally } \\
\text { taken from their natural } \\
\text { deposit without changing } \\
\text { their nature during the } \\
\text { process of production such } \\
\text { as grinding and crushing. } \\
\text { Manufactured (synthetic) } \\
\text { aggregate: these are man- } \\
\text { made materials produced as } \\
\text { a main product or an } \\
\text { industrial by-product such } \\
\text { as blast furnace slag, and } \\
\text { light weight aggregate. }\end{array}$ \\
\hline 3 & $\begin{array}{l}\text { According to Unit } \\
\text { Weight }\end{array}$ & $\begin{array}{l}\text { Light weight aggregate: } \\
\text { when the unit weight of } \\
\text { aggregate is less than } \\
1120 \mathrm{~kg} / \mathrm{m}^{3} \text { and the } \\
\text { corresponding concrete has } \\
\text { a bulk density less than } \\
1800 \mathrm{~kg} / \mathrm{m}^{3} \text {. } \\
\text { Normal weight or average } \\
\text { weight aggregate: when the } \\
\text { aggregate has a unit weight } \\
\text { of between } 1520- \\
1680 \mathrm{~kg} / \mathrm{m}^{3} \text {, and has a } \\
\text { concrete bulk density of } \\
2300-2400 \mathrm{~kg} / \mathrm{m}^{3} \\
\text { Heavy weight aggregate: the } \\
\text { unit weight is greater than } \\
2100 \mathrm{~kg} / \mathrm{m}^{3}\end{array}$ \\
\hline
\end{tabular}




\section{International Journal of Engineering Applied Sciences and Technology, 2020 \\ Vol. 5, Issue 2, ISSN No. 2455-2143, Pages 1-7 \\ Published Online June 2020 in IJEAST (http://www.ijeast.com)}

Aggregates can also be classified based on the type of rock it was crushed from. For instance, igneous, metamorphic, or sedimentary rock. Aggregates are classified under igneous rocks depending on origin, grain size and composition of the rock [3]. Furthermore, they can be classified as sedimentary based on calcareous, siliceous, and argillaceous. Metamorphic rocks may be classified as artificial aggregates or by-products of industrial processes such as blast furnace slag [3]. Consequently, according to Christina [9], the Minnesota aggregate classification classified aggregates into six main classes; class A, class B, Class C, class D, class E and class R as can be seen in table 2 below

Table 2: The Six Minnesota aggregate classification [9]

\begin{tabular}{|c|c|l|}
\hline S/N & Class & \multicolumn{1}{|c|}{ Classification } \\
\hline $\mathbf{1}$ & Class A & $\begin{array}{l}\text { Crushed igneous bedrock } \\
\text { (specifically basalt, granite, rhyolite, } \\
\text { and diorite rocks from Sioux } \\
\text { Quartzite formation } \\
\text { Crushed rocks from all other bedrock } \\
\text { sources as carbonate and } \\
\text { metamorphic rocks (gneiss or Schist) }\end{array}$ \\
\hline $\mathbf{2}$ & Class B & $\begin{array}{l}\text { Consist of natural or partly crushed } \\
\text { natural gravel obtained from gravel } \\
\text { deposit }\end{array}$ \\
\hline $\mathbf{3}$ & Class C \\
\hline $\mathbf{5}$ & Class E & $\begin{array}{l}\text { Consist of 100\% natural gravel } \\
\text { Consist of a mixture of any two or } \\
\text { more of class A, B and/or D } \\
\text { Consist of aggregate obtained from } \\
\text { recycling of concrete which will be } \\
\text { crushed to specific gradation }\end{array}$ \\
\hline
\end{tabular}

\section{B. PROPERTIES OF AGGREGATE}

Aggregate properties are often expressed as physical, chemical, and thermal, respectively. Each with a unique and important role in the final product which the aggregates are used for. Physical properties are classified according to density and specific gravity, unit weight and moisture content. The specific gravity and water absorption capacity of coarse aggregate are key parameters in design and construction of any structure using aggregates [10,11]. The American Association of State Highway and Transportation Officials (AASHTO) standards defined specific gravity of an aggregates as the ratio of the density of a material to the density of distilled water at a stated temperature, the value being dimensionless [11]. Consequently, the water absorption of an aggregate is the increase in mass due to water penetration into the pores of the particle during a specified period of time, but not including water adhering to the outside surface of the particles, expressed as the percentage of the dry mass [11].

Aggregates which are often used as cement ingredients occupy nearly about $70-75 \%$ volume of concrete. However, it is now recognized that physical, chemical, and thermal properties of aggregate substantially influence the properties and performance of concrete [5]. One of the important physical properties of coarse aggregate is the determination of its specific gravity and water absorption.

\section{MATERIALS AND METHODS}

There are different methods of determining the physical properties of aggregates. However, this research focusses on the AASHTO T85 and ASTM C-127 standards to measure the specific gravity and water absorption rates of commonly used aggregates in Jos. This approach involves the soaking of the coarse aggregate samples for 15hours (AASHTO T 85) and 24 \pm 4 hours (ASTM C-127), and drying the aggregate to its saturated-surface dry (SSD) state with the aid of a dry absorbent cloth [10,12]. Although Mills-Beale [10] considers this method subjective, it has been used widely to compute for the water absorption and specific gravity of aggregates in the construction industry. More so, it is the easiest way to compute for these parameters without requiring sophisticated laboratory procedures and equipment. Therefore, the choice of our methods in determining the suitability of use of hand crushed aggregates against the mechanically crushed aggregates in Jos Nigeria.

\section{List of Equipment and Materials}

- Weighing balance (not less than $5 \mathrm{~kg}$ capacity)

- Thermostatically controlled Oven

- Glass Vessel

- Airtight container

- $10 \mathrm{~mm}$ IS Sieve

- Coarse aggregate (sample under Test)

- Observation Sheet

\section{A. THE STUDY AREA}

Plateau state is in Nigeria's middle belt with an average area of $26,899 \mathrm{~km}^{2}$. it is located within an average altitude of $1,200 \mathrm{~m}$ to $1829 \mathrm{~m}$ above sea level and surrounded by rocks and so many natural resources. Plateau State is surrounded by Kaduna State, Bauchi State, Nasarawa State and Taraba State as seen in figure 2 below. The Jos Plateau is thought to be an area of granite rocks as old as 160 million years old. This makes the area in abundance of rocks which have been crushed for various construction works. These rocks have been crushed both manually by the locals as well as mechanically by construction companies and the government. 


\section{International Journal of Engineering Applied Sciences and Technology, 2020 \\ Vol. 5, Issue 2, ISSN No. 2455-2143, Pages 1-7 \\ Published Online June 2020 in IJEAST (http://www.ijeast.com)}

A total of nine (9) sampling sites were located and surveyed within the region. However, only three (3) sites had both mechanically crushed (MC) and hand crushed (HC) aggregates sold within the area. Therefore, only three sampling sites were selected for this research. The selected sites were designated with symbolic names of sampling sites $\mathrm{X}, \mathrm{Y}$ and $\mathrm{Z}$ respectively for easy identification. In each of the sampling sites, a triplicate of $1000 \mathrm{~g}$ of aggregate were collected for each of the two categories under investigation (mechanically and hand crushed aggregates). These were labelled as sample I, II, and III respectively. The average of the results computed was then tabulated and analysed statistically to determine the significant difference and presented in the discussion section.

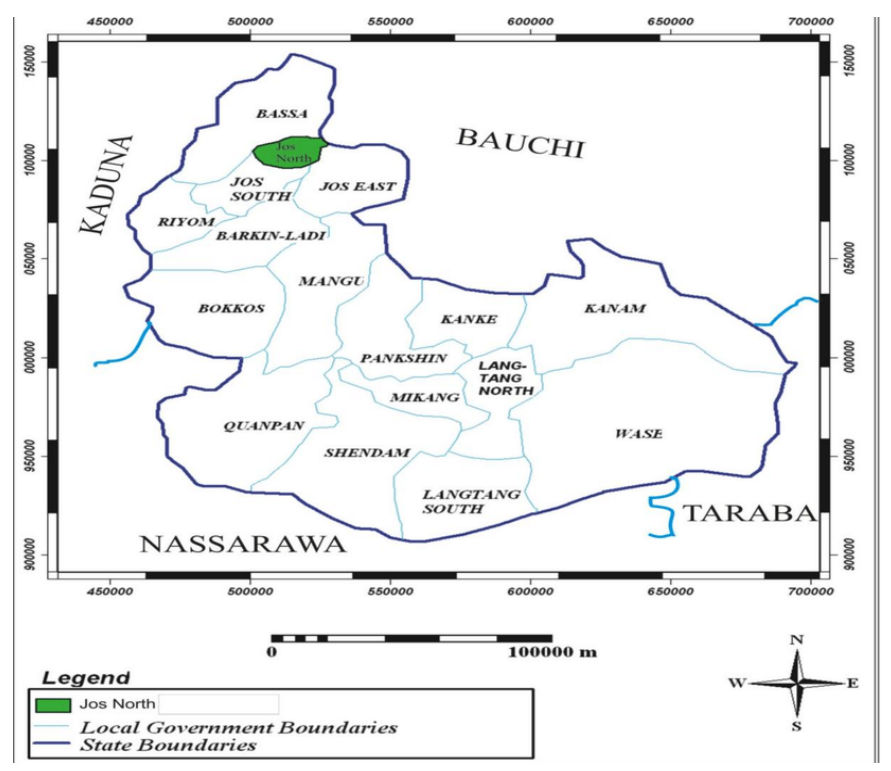

Fig 1: Map of Jos showing the sampling area [13]

\section{B. Methodology}

The methodology was according to the specification of the BSG as described in [6] and stated as follows;

- Take approximately $1 \mathrm{~kg}$ of sample of coarse aggregate in its natural state. The quantity to be taken depends on the size of the aggregate

- Sieve the sample to $10 \mathrm{~mm}$ highest sieve to remove the finer particles

- $\quad$ Place the sieved sample in the glass vessel and partly submerge the sample in water

- Keep the aggregate immersed for 24 hours so that they are completely saturated

- Remove entrapped air at the end of 24 hours by gentle agitation
- Fill the vessel with water and close to ensure no air is present before weighing the vessel containing water and the sample

- Empty the vessel and allow the aggregate to drain out

- Place the aggregate on a dry cloth until it reaches surface dry condition

- Refill the vessel with distilled water, close it to ensure no entrapped air is present. Weigh the vessel and record the reading

Specific gravity was defined as the ratio of the weight of aggregate in air to the weight of equal volume of water displaced by saturated surface dry aggregate. Specific gravity for all samples under test was computed using the equation.

$$
S G=\frac{W 1}{W 2-(W 3-W 4)}
$$

Where.

W1 = Weight of oven dry sample

W2 = Weight of saturated surface dry sample

W3 = Weight of sample + Vessel + Water

W4 $=$ Weight of vessel and water

Apparent Specific Gravity was also computed using the equation.

$$
A S G=\frac{W 1}{W 1-(W 3-W 4)}
$$

Subsequently, the Water Absorption rate of coarse aggregate was computed from the equation.

$$
W A=\frac{W 3-W 1}{W 1} \times 100
$$

An average value of the three samples (triplicate sample for all 3 sample sites) is taken as the result of the experiment. This value was taken as the final result for the experiment and tabulated. These values were for aggregates between $10 \mathrm{~mm}$ and $40 \mathrm{~mm}$ particle size.

\section{The Study Hypothesis}

The study hypothesis suggests that there exists a statistically significant difference between the mechanically crushed aggregates and hand crushed aggregates in comparison to the standard building code (average value of 2.7). It also suggests that there is a significant difference in water absorption of the 


\section{International Journal of Engineering Applied Sciences and Technology, 2020 \\ Vol. 5, Issue 2, ISSN No. 2455-2143, Pages 1-7 \\ Published Online June 2020 in IJEAST (http://www.ijeast.com)}

two types of aggregates under investigation. The two hypotheses are given below as follows;

1. The null hypothesis $\left(\mathbf{H}_{0}: \boldsymbol{\mu}=\mathbf{2 . 7}\right)$ - There is no significant difference in the mean specific gravity of mechanically crushed and hand crushed aggregates in comparison to the mean standards of 2.7 .

- The alternate hypothesis $\left(\mathbf{H}_{\mathbf{1}}: \boldsymbol{\mu} \neq \mathbf{2 . 7}\right)$ - There is a significant difference in the mean specific gravity of the two aggregates in comparison to the mean standards of 2.7 .

2. The null hypothesis $\left(\mathbf{H}_{\mathbf{0}}: \boldsymbol{\mu}=\mathbf{0 . 6 \%}\right)-$ There is no significant difference in the mean water absorption of the two aggregates in comparison to the mean standards of $0.68 \%$

- The alternate hypothesis $\left(\mathbf{H}_{\mathbf{1}}: \boldsymbol{\mu} \neq \mathbf{0 . 6 \%}\right)$ - There is a significant difference in the mean water absorption of the two aggregate types in comparison to the mean standards of $0.68 \%$

\section{RESULT AND DISCUSSION}

From the three sampling sites ( $\mathrm{X}, \mathrm{Y}$ and $\mathrm{Z}$ ), the specific gravity, and water absorption were computed and tabulated. The results were then subjected to statistical analysis to test for the hypothesis and determine the compliance rate of both aggregates to the standard values stipulated by the building codes as shown in tables $3-14$ below.

\section{A. Sampling Site $\mathbf{X}$}

A One-sample t-Test was carried out to test the hypothesis and determine the significant difference in the mean of the variables measured to the standard means stipulated by the building codes. The results of the t-Test suggest that the mean for MC specific gravity, MC and $\mathrm{HC}$ water absorption rates with $p$ values of $0.107(\mathrm{p}>0.05), 0.383(\mathrm{p}>0.05)$ and 0.927 $(p>0.05)$ were not significantly different from the mean of the stipulated values of 2.7 (specific gravity) and $0.6 \%$ (water absorption rates of aggregates). Therefore, the study fails to reject the null hypothesis. However, the results for $\mathrm{HC}$ specific gravity with a $\mathrm{p}$ value of 0.001 is significantly differently from the target mean $(p<0.05)$. Hence, the study rejects the null hypothesis.

Table 3: One-Sample T - Test: MC specific gravity for sample site $\mathrm{X}$

\begin{tabular}{|l|l|l|l|l|l|l|}
$\mathrm{N}$ & Mean & St. Dev & $\begin{array}{l}\text { SE } \\
\text { Mean }\end{array}$ & $\begin{array}{l}95 \% \\
\text { CI for } \\
\mu\end{array}$ & $\begin{array}{l}\text { T - } \\
\text { Value }\end{array}$ & $\begin{array}{l}\text { Palue } \\
\text { Val }\end{array}$ \\
\hline $\mathbf{2 0}$ & 2.7515 & 0.1360 & 0.304 & $\begin{array}{l}2.687, \\
2.81\end{array}$ & 1.69 & 0.107 \\
\hline
\end{tabular}

Table 4: One-Sample T - Test: HC specific gravity for sample

\begin{tabular}{|l|l|l|l|l|l|l|}
\hline N & Mean & St. Dev & $\begin{array}{l}\text { SE } \\
\text { Mean }\end{array}$ & $\begin{array}{l}\text { 95\% } \\
\text { CI for } \\
\mu\end{array}$ & $\begin{array}{l}\text { T }- \\
\text { Value }\end{array}$ & $\begin{array}{l}\text { P }- \\
\text { Value }\end{array}$ \\
\hline $\mathbf{2 0}$ & 2.354 & 0.1553 & 0.0347 & $\begin{array}{l}2.281, \\
2.42\end{array}$ & -9.96 & 0.001 \\
\hline
\end{tabular}

Table 5: One-Sample T - Test: MC water absorption (\%) for sample site $\mathrm{X}$

\begin{tabular}{|l|l|l|l|l|l|l|}
\hline $\mathrm{N}$ & Mean & St. Dev & $\begin{array}{l}\text { SE } \\
\text { Mean }\end{array}$ & $\begin{array}{l}95 \% \\
\text { CI for } \\
\mu\end{array}$ & $\begin{array}{l}\text { T }- \\
\text { Value }\end{array}$ & $\begin{array}{l}\mathrm{P}- \\
\text { Value }\end{array}$ \\
\hline $\mathbf{2 0}$ & 0.602 & 0.0125 & 0.2228 & $\begin{array}{l}0.596, \\
0.60\end{array}$ & 0.89 & 0.383 \\
\hline
\end{tabular}

Table 6: One-Sample T - Test: HC water absorption (\%) for sample site $\mathrm{X}$

\begin{tabular}{|l|l|l|l|l|l|l|}
\hline $\mathrm{N}$ & Mean & St. Dev & $\begin{array}{l}\text { SE } \\
\text { Mean }\end{array}$ & $\begin{array}{l}95 \% \\
\text { CI for } \\
\mu\end{array}$ & $\begin{array}{l}\text { T }- \\
\text { Value }\end{array}$ & $\begin{array}{l}\text { Palue } \\
\text { Valu }\end{array}$ \\
\hline $\mathbf{2 0}$ & 0.599 & 0.0239 & 0.00535 & $\begin{array}{l}0.588, \\
0.61\end{array}$ & -0.09 & 0.927 \\
\hline
\end{tabular}

\section{B. Sampling Site Y}

Sampling site Y reveals similar results to sample site $\mathrm{X}$. The tTest shows that MC specific gravity with a p-value of $0.539(\mathrm{p}$ $>0.05), \mathrm{MC}$ and $\mathrm{HC}$ water absorption with p-values of 0.963 ( $p>0.05)$ and $0.355(\mathrm{p}>0.05)$ have means that were not significantly different from the stipulated guideline codes of 2.7 (for specific gravity) and $0.6 \%$ (for water absorption). Therefore, the study fails to reject the null hypothesis. Consequently, hand crushed (HC) aggregates with a p-value of 0.001 ( $\mathrm{p}<0.05$ ) shows to have a significant difference with the stipulated guideline code of 2.7. Hence, the study rejects the null hypothesis.

Table 7: One-Sample T - Test: MC specific gravity for sample

\begin{tabular}{|l|l|l|l|l|l|l|}
\hline N & Mean & $\begin{array}{l}\text { St. } \\
\text { Dev }\end{array}$ & $\begin{array}{l}\text { SE } \\
\text { Mean }\end{array}$ & $\begin{array}{l}\text { 95\% } \\
\text { CI for } \\
\mu\end{array}$ & $\begin{array}{l}\text { T }- \\
\text { Value }\end{array}$ & $\begin{array}{l}\text { Palue } \\
\text { Valu }\end{array}$ \\
\hline $\mathbf{2 0}$ & 2.718 & 0.128 & 0.0288 & $\begin{array}{l}2.657, \\
2.77\end{array}$ & 0.63 & 0.539 \\
\hline
\end{tabular}

Table 8: One-Sample T - Test: HC specific gravity for sample

\begin{tabular}{|l|l|l|l|l|l|l|}
\hline N & Mean & $\begin{array}{l}\text { St. } \\
\text { Dev }\end{array}$ & $\begin{array}{l}\text { SE } \\
\text { Mean }\end{array}$ & $\begin{array}{l}\text { 95\% } \\
\text { CI for } \\
\mu\end{array}$ & $\begin{array}{l}\text { T }- \\
\text { Value }\end{array}$ & $\begin{array}{l}\text { Palue } \\
\text { Value }\end{array}$ \\
\hline $\mathbf{2 0}$ & 2.371 & 0.132 & 0.0297 & $\begin{array}{l}2.308, \\
2.43\end{array}$ & -11.07 & 0.001 \\
\hline
\end{tabular}




\section{International Journal of Engineering Applied Sciences and Technology, 2020 \\ Vol. 5, Issue 2, ISSN No. 2455-2143, Pages 1-7 \\ Published Online June 2020 in IJEAST (http://www.ijeast.com)}

Table 9: One-Sample T - Test: MC water absorption for sample site $\mathrm{Y}$

\begin{tabular}{|l|l|l|l|l|l|l|}
\hline $\mathrm{N}$ & Mean & St. Dev & $\begin{array}{l}\text { SE } \\
\text { Mean }\end{array}$ & $\begin{array}{l}95 \% \\
\text { CI for } \\
\mu\end{array}$ & $\begin{array}{l}\mathrm{T}- \\
\text { Value }\end{array}$ & $\begin{array}{l}\mathrm{P}- \\
\text { Value }\end{array}$ \\
\hline $\mathbf{2 0}$ & 0.599 & 0.0476 & 0.0106 & $\begin{array}{l}0.577, \\
0.62\end{array}$ & -0.05 & 0.963 \\
\hline
\end{tabular}

Table 10: One-Sample T - Test: Hand Crushed (HC) water absorption for sample site Y

\begin{tabular}{|l|l|l|l|l|l|l|}
\hline $\mathrm{N}$ & Mean & St. Dev & $\begin{array}{l}\text { SE } \\
\text { Mean }\end{array}$ & $\begin{array}{l}95 \% \\
\text { CI for } \\
\mu\end{array}$ & $\begin{array}{l}\text { T } \\
\text { Value }\end{array}$ & $\begin{array}{l}\mathrm{P}- \\
\text { Value }\end{array}$ \\
\hline $\mathbf{2 0}$ & 0.587 & 0.0589 & 0.0132 & $\begin{array}{l}0.559, \\
0.61\end{array}$ & -0.95 & 0.355 \\
\hline
\end{tabular}

\section{Sampling Site Z}

$\mathrm{T}$-Test for sampling site $\mathrm{Z}$ reveals that the mean for specific gravity of mechanically crushed (MC) aggregates with $\mathrm{p}$ value of $0.188(p>0.05)$ is not significantly different from the mean of the stipulated code of 2.7. Therefore, the study fails to reject the null hypothesis. However, the mean for $\mathrm{HC}$ specific gravity, $\mathrm{MC}$ and $\mathrm{HC}$ water absorption with $\mathrm{p}$ values of 0.001 ( $\mathrm{p}<0.05), 0.001(\mathrm{p}<0.05)$ and $0.025(\mathrm{p}<0.05)$ reveal that there exists a significant difference in mean when compared to the stipulated guiding code. Hence, the study rejects the null hypothesis as can be seen from tables $11-14$ below.

Table 11: One-Sample T - Test: Mechanically Crushed (MC) specific gravity for sample site $\mathrm{Z}$

\begin{tabular}{|l|l|l|l|l|l|l|}
\hline $\mathrm{N}$ & Mean & $\begin{array}{l}\text { St. } \\
\text { Dev }\end{array}$ & $\begin{array}{l}\text { SE } \\
\text { Mean }\end{array}$ & $\begin{array}{l}95 \% \\
\text { CI for } \\
\mu\end{array}$ & $\begin{array}{l}\text { T } \\
\text { Value }\end{array}$ & $\begin{array}{l}\text { Palue } \\
\text { Value }\end{array}$ \\
\hline $\mathbf{2 0}$ & 4.86 & 7.06 & 1.58 & $\begin{array}{l}1.55, \\
8.16\end{array}$ & 1.37 & 0.188 \\
\hline
\end{tabular}

Table 11: One-Sample T - Test: Hand Crushed (HC) specific gravity for sample site $\mathrm{Z}$

\begin{tabular}{|l|l|l|l|l|l|l|}
\hline $\mathrm{N}$ & Mean & St. Dev & $\begin{array}{l}\text { SE } \\
\text { Mean }\end{array}$ & $\begin{array}{l}\text { 95\% } \\
\text { CI for } \\
\mu\end{array}$ & $\begin{array}{l}\text { T }- \\
\text { Value }\end{array}$ & $\begin{array}{l}\text { Value } \\
\text { Value }\end{array}$ \\
\hline $\mathbf{2 0}$ & 2.349 & 0.1879 & 0.0420 & $\begin{array}{l}2.261, \\
2.43\end{array}$ & -8.35 & 0.001 \\
\hline
\end{tabular}

Table 11: One-Sample T - Test: Mechanically Crushed (MC) water absorption for sample site $\mathrm{Z}$

\begin{tabular}{|c|c|c|c|c|c|c|}
\hline $\mathrm{N}$ & Mean & St. Dev & $\begin{array}{l}\text { SE } \\
\text { Mean }\end{array}$ & $\begin{array}{l}95 \% \\
\mathrm{CI} \text { for } \\
\mu\end{array}$ & $\begin{array}{l}\mathrm{T}- \\
\text { Value }\end{array}$ & $\begin{array}{l}\mathrm{P} \quad- \\
\text { Value }\end{array}$ \\
\hline 20 & 0.636 & 0.0301 & 0.0067 & $\begin{array}{l}0.622, \\
0.65\end{array}$ & 5.42 & 0.001 \\
\hline
\end{tabular}

Table 11: One-Sample T - Test: Hand Crushed (HC) water absorption for sample site $\mathrm{Y}$

\begin{tabular}{|l|l|l|l|l|l|l|}
\hline N & Mean & $\begin{array}{l}\text { St. } \\
\text { Dev }\end{array}$ & $\begin{array}{l}\text { SE } \\
\text { Mean }\end{array}$ & $\begin{array}{l}\text { 95\% } \\
\text { CI for } \\
\mu\end{array}$ & $\begin{array}{l}\text { T } \\
\text { Value }\end{array}$ & $\begin{array}{l}\text { Value } \\
\text { Valu }\end{array}$ \\
\hline $\mathbf{2 0}$ & 0.546 & 0.098 & 0.022 & $\begin{array}{l}0.500, \\
0.59\end{array}$ & -2.43 & 0.025 \\
\hline
\end{tabular}

\section{CONCLUSION}

Standards and building codes in engineering are developed to guide and aid engineers in achieving standard structures that will be durable to withstand load. The construction industry is an especially important sector that must adhere to standards. This is true because roads, and concrete are sensitive aspects of structures that needs to adhere to standards because their failure can cause a devastating impact on people and the environment. This study assessed the specific gravity and water absorption of aggregates and subjected the results to TTest to determine the difference in the mean to the standard guidelines. The findings from this assessment shows that there are significant differences in the specific gravity and water absorption rates of aggregates between the mechanically crushed and hand crushed aggregates when compared to the stipulated building guidelines. Therefore, it is recommended that engineers and builders always carry out these tests regularly in order to ensure strict compliance to standard building regulations. Furthermore, concrete and road or any structure constructed with these aggregates within the Jos province, should be tested before they are used for any construction work so as to avoid any unforeseen structural failure.

\section{REFERENCE}

[1] Babick, F., (2016). Suspensions of Colloidal Particles and Aggregates. Cham: Springer International Publishing.

[2] Sinecen, M., Topal, A., Makinaci, M. \& Baradan, B., (2013). Neural network classification of aggregates by means of line laser based 3D acquisition. Expert Systems. [online] 30(4), pp.333-340. [viewed 20 January 2019]. Available from: http://10.1111/j.14680394.2012.00638.x

[3] Reid., J.M., Chandler., J.W.E., Schiavil., I., Hewitt., A., Griffiths., R.\& Bendall., E., (2008). Sustainable Choice of Material for Highway Works. A Guide for Local Authority Highway Engineers. UK: Copyright Queens Printer and Controller of HMSO.

[4] Tepordei, V., (1999). Natural Aggregate - Foundation of America's future. United State Geological Survey (USGS) Fact Sheet FS 144-97. Available from: https://pubs.er.usgs.gov/publication/fs14497 
[5] Tucker, F.H., (1925). Apparatus for Determining the Specific Gravity of Aggregates. Industrial \& Engineering Chemistry. [online] 17(5), pp.517-520. [viewed 16 July 2019]. Available from: http://10.1021/ie50185a033

[6] British Geological Survey., (1994). Report on the Industrial Mineral Laboratory Manual. Construction Materials. Swindon: British Geological Survey.

[7] Mitchell, C.B.G., (2015). Construction aggregates: evaluation and specification. paper. UK: BGS [Viewed 17 July 2019].Available from: http://nora.nerc.ac.uk/id/eprint/510909/1/Constructi on $\% 20$ aggregates $\% 20$ evaluation $\% 20$ and $\% 20$ specification .pdf.

[8] Mitchell, C. Good Quarry Production Technology., (2007).Encyclopedias of the Natural World: Encyclopaedia of Biological Invasions. UK: MIST \& BGS [Viewed 16 July 2019].Available from: http://nora.nerc.ac.uk/id/eprint/15899/1/GoodQuarr y_Production_Technology.pdf.

[9] Christina, M., (2012). Construction Aggregate; the foundation of everyday life. Minnesota Mineral Education Workshop. Tiler Cooperation's Land Use Department US.

[10] Mills-Beale, J., You, Z., Williams, R.C. \& Dai, Q., 2009. Determining the specific gravities of coarse aggregates utilizing vacuum saturation approach. Construction and Building Materials; Construction and Building Materials. [online] 23(3), pp.1316-1322. [viewed 16 July 2019]. Available from: http://10.1016/j.conbuildmat.2008.07.025

[11] You, Z., Mills-Beale, J., Williams, R. \& Dai, Q., (2009). Measuring the Specific Gravities of Fine Aggregates: An Automated Procedure. International Journal of Pavement Research and Technology. [online] 2(2), pp.37-50. [viewed 16 July 2019]. Available from: http://10.6135/ijprt.org.tw/2009.2(2).37

[12] Sinecen, M. \& Makinaci, M., (2010). Classification of Aggregates Using Basic Shape Parameters Through Neural Networks. Pamukkale University Journal of Engineering Sciences. [online] 16(2), pp.149-153. [viewed 10 July 2019]. Available from: http://pajes.pau.edu.tr/eng/jvi.asp?pdir=pajes\&plng =eng\&volume $=16 \&$ issue $=2$.

[13] Antipas G.R, Agbubata K.A, Lekwot V.E, Ali A.Y, Danjuma A.K, \& Abdulrahman A.S. (2015). Population increase and water supply in Nigerian cities: case study of Jos in Plateau State, Nigeria. International Journal of Multidisciplinary and Current Research, 3(2015), pp.2331 